\title{
Plumb, Guyton and path: polysemy of health from the perspective of college students
}

\author{
Marieli Mezari Vitali ${ }^{1}$ \\ https://orcid.org/0000-0003-0052-7788 \\ Maria Fernanda Araújo² \\ https://orcid.org/0000-0001-7374-0796
}

Fabiane Ferraz ${ }^{3}$

https://orcid.org/0000-0003-1782-6784

Luciane Bisognin Ceretta 4

https://orcid.org/0000-0002-2682-5567

Jacks Soratto 5

https://orcid.org/0000-0002-1339-7268
Universidade Federal de Santa Catarina UFSC, Florianópolis, Santa Catarina Brasil. Universidade do Extremo Sul Catarinense - UNESC, Programa de Pós-Graduação em Saúde Coletiva Criciúma, Santa Catarina, Brasil.

${ }^{3}$ Universidade do Extremo Sul Catarinense - UNESC, Curso de Graduação em Enfermagem, Residência Multiprofissional em Atenção Básica e Saúde Coletiva e, Programa de Pós-Graduação em Saúde Coletiva (Mestrado Profissional), Criciúma, Santa Catarina, Brasil.

${ }^{4}$ Universidade do Extremo Sul Catarinense - UNESC, Programa de Pós-graduação em Saúde Coletiva, Criciúma, Santa Catarina, Brasil.

${ }^{5}$ Universidade do Extremo Sul Catarinense - UNESC, Curso de Graduação em Enfermagem, Medicina, Residência Multiprofissional em Atenção Básica e Saúde Coletiva e, Programa de Pósgraduação em Saúde Coletiva (Mestrado Profissional), Criciúma, Santa Catarina, Brasil.

Research support source: Notice number 15/2017 of the Programa Institucional de Bolsas de Iniciação Cientifica (PIBIC), of the Universidade do Extremo Sul Catarinense (UNESC) in agreement with the Conselho Nacional de Desenvolvimento Cientifico e Tecnológico (CNPq).

Conflict of interests: Nonexistent

\section{(C) (i)}

Received on: May 19, 2019 Accepted on: October 30, 2019

Corresponding address: Marieli Mezari Vitali

Rua Capitão Osmar Silva, 420, Pantanal CEP: 88040-150 Florianópolis,

Santa Catarina, Brasil

E-mail: marielimezari@gmail.com

\section{ABSTRACT}

Purpose: to identify the understanding of health of college students enrolled in health programs of a university in the South of Brazil.

Methods: a qualitative, descriptive and exploratory research conducted by means of an online questionnaire with students of health programs. The data were analyzed according to the thematic content analysis with the aid of Atlas.ti software.

Results: there were 233 answers, structured in 20 codes, 7 subcategories and 3 categories: health associated with well-being, balance and quality of life; health connected with the biological and absence of diseases; and health related to the capacity to act and the notion of wholesomeness.

Conclusion: the understanding of health for college students is expressed in a polysemic way, but with a predominating comprehension linked to the notion of well-being and balance.

Keywords: Students; Curriculum; Health; Health Education 


\section{INTRODUCTION}

The understanding of health is a subject of various debates. The diversified comprehension on the meaning of health runs through social, cultural, economic, political and religious factors. Throughout history, the perception of health has been related to the concept of disease 1 . Some researchers, institutions and social movements have contributed to build the multiple understanding involving the idea of health.

Throughout time, historians, scientists and philosophers, like Hippocrates [400 BC], Descartes [15961650], François Xavier Bichat [1771-1802], Abraham Flexner Henry [1866-1959], Charles-Edward Winslow [1877-1957], Henry Ernest Sigerist [1891-1957], Michel Foucault [1926-1984], Geoges Canguilhem [19041995], and Christopher Boorse [1946-present day], have highlighted multiple approaches regarding the comprehension of what health is, with contributions from many fields of knowledge, from physiology to statistics, philosophy and even anthropology. Thus, has been understood from magical and religious perceptions, subjective and individual experiences, as simply the absence of a disease, as a state of well-being, or as social value ${ }^{2}$.

Among the perception on health, the one that has perpetuated longest in the field of theory and in the picture of practices is the one conceived by the World Health Organization (WHO), which defines it as a state of complete physical, mental and social well-being, and not only the absence of diseases and illnesses ${ }^{3}$. Such perception was formed in the constitution of this organization, serving as a basis for developing governmental health policies, and hence institutionalized by the member countries ${ }^{3}$.

This definition, which expresses the longing for a full life, without the postwar privations ${ }^{4}$, regrouped different dimensions of life on the perception of health, in opposition to the biomedical and physiological model hegemonic up until then. However, it is defined by many as utopic, unattainable, in addition to subjective and, therefore, difficult to be used by the health services.

Furthermore, "by not distinguishing health and normality, pathology and anomaly, this definition allows that any variability be considered as pathological and, consequently, as medicable: ${ }^{4: 102 ", ~ e s p e c i a l l y ~}$ with the disease-focused studies. This was one of the aspects that brought criticism to the concept, for its utopic character, as well as for it making possible a comprehension based on the need of a medicalizing intervention on life, since full health is unattainable.

It is known that the health professionals are the main ones contributing to pulverize the perceptions on health. The health professions have their competences and attributions, whose job presupposes their understanding on the subject. Nevertheless, many times they do not sustain what such perception is, contemplating it in a "short-sighted" manner.

Few are the studies that approach this theme broadly when these professionals are being trained. The studies that do so, refer to the perception based on experiences in specific programs, as the PET-Saúde ${ }^{5,6}$, or to issues related to the professional practice, as health care $^{7}$ and health education ${ }^{8}$, without there being an in-depth look into the perception of what health is.

Therefore, it is important that the training in the graduation level health programs strengthen the understanding on the definitions of the concept of health, the process of health and disease, and its implications on practice. Having in mind the many concepts on health and the discussions that have been raised regarding it, the objective of this study was to identify the perception on health among college students enrolled in programs in the field of health at a university in the South of Brazil.

\section{METHODS}

This study is an exploratory descriptive research with a qualitative approach ${ }^{9}$. The collection of data took place from August 2 to September 13, 2017, after the research had been approved by the Human Research Ethics Committee of the Universidade do Extremo Sul Catarinense, under evaluation report number 2.201.297. The anonymity of the participants was ensured by means of an alphanumeric code composed of two letters and the cardinal number; hence, the first letter is $\mathrm{P}$, and the second letter is the initial of the program which the student is enrolled in, for instance: PB 153, which means a biomedicine student whose answer is number 153 .

The research was conducted by means of convenience sampling with 233 students of programs related to health professions at a university in the south of the state of Santa Catarina. Only students regularly enrolled in the programs participated, whereas students from other fields of knowledge taking isolated courses were excluded. Table 1 shows the participants' profile: 
Table 1. Characterization of the participants in the research

\begin{tabular}{|c|c|c|c|}
\hline & Variables & n & $\%$ \\
\hline \multirow{2}{*}{ Gender } & Female & 190 & 81.5 \\
\hline & Male & 43 & 18.5 \\
\hline \multirow{6}{*}{ Age group } & $15-20$ & 86 & 36.9 \\
\hline & $20-24$ & 104 & 44.6 \\
\hline & $25-30$ & 29 & 12.5 \\
\hline & $31-35$ & 5 & 2.1 \\
\hline & $36-40$ & 6 & 2.6 \\
\hline & $41-45$ & 3 & 1.3 \\
\hline \multirow{10}{*}{ Program } & Biomedicine & 22 & 9.5 \\
\hline & Biology & 9 & 3.9 \\
\hline & Physical Education & 9 & 3.9 \\
\hline & Nursing & 17 & 7.3 \\
\hline & Pharmacy & 27 & 11.5 \\
\hline & Physiotherapy & 21 & 9 \\
\hline & Medicine & 29 & 12.5 \\
\hline & Nutrition & 41 & 17.5 \\
\hline & Odontology & 21 & 9 \\
\hline & Psychology & 37 & 15.9 \\
\hline \multirow{11}{*}{ Semester } & 1st semester & 63 & 27 \\
\hline & 2nd semester & 38 & 16.4 \\
\hline & 3rd semester & 14 & 6 \\
\hline & 4th semester & 16 & 6.8 \\
\hline & 5th semester & 17 & 7.4 \\
\hline & 6th semester & 16 & 6.8 \\
\hline & 7th semester & 20 & 8.5 \\
\hline & 8th semester & 30 & 12.8 \\
\hline & 9th semester & 8 & 3.5 \\
\hline & 10th semester & 10 & 4.3 \\
\hline & 12th semester & 1 & 0.5 \\
\hline \multirow{7}{*}{ Income } & 1 salary & 35 & 15 \\
\hline & 2 salaries & 47 & 20.2 \\
\hline & 3 to 4 salaries & 91 & 39 \\
\hline & 5 to 6 salaries & 38 & 16.3 \\
\hline & 7 to 8 salaries & 8 & 3.5 \\
\hline & 9 to 10 salaries & 6 & 2.5 \\
\hline & Over 11 salaries & 8 & 3.5 \\
\hline Total & & 233 & 100 \\
\hline
\end{tabular}

Source: data from the research, 2019.

There was a predominance of female participants, aged from 20 to 24 years and income between three and four minimum salaries. The programs of Nutrition, Psychology and Medicine were the ones with the most adherence to the research, especially of students from the first, second and eighth semesters.

The instrument for collecting data was a questionnaire composed of seven closed-ended questions related to the participants' characterization, and three open-ended questions aimed at identifying the understanding of the participants regarding the theme.

The questionnaire was developed on Google Forms and sent only once to the students via e-mail through the coordination of the programs. The body of the e-mail contained an explanation of the goals of the research, contact in case of questions, and a link that, when clicked, would lead to the instrument. In the electronic form, the first information presented was 
the Informed Consent Form (ICF), with the details of the whole process of investigation, as well as an icon where to attest the consent.

The data were organized by means of the Atlas.ti software ${ }^{10}$, which is a program that aids the researcher in the analysis, making storage and management of data easier; i.e., it does not offer an interpretation of the results ${ }^{10}$. After being organized, the data were analyzed by means of the content analysis technique ${ }^{10,11}$, composed of three phases: pre-analysis, exploration of the material, and lastly, treatment of the results and interpretation.

The pre-analysis was characterized by systematization of and organization of the collected material; the file with the data was extracted from the digital platform in .xls format, pre-analytical reading was performed, the data were refined, presuppositions were questioned and the writing was adjusted. In this phase, pre-analysis of 299 answers was conducted, and 66 were excluded, namely: two (2) for being repeated; fourteen (14) for not having clicked to accept the ICF; twenty-seven (27) for not having answered all the questions in the form; twenty-three (23) for having answers inconsistent with what had been asked, e.g., "I'm just seeing the form, I do not intend to participate", etc.

The exploration of the material consisted in coding the data. The file with collected and filtered data was inserted in the Atlas.ti software, which enabled the answer excerpts (quotations) to be selected, represented by means of codes or subcategories (codes), and group them by categories (code groups) that reflected the content of what had been said. To name the codes, subcategories and categories, the theoretical support of productions related to the concept of health was taken into account.

In the stage of treating and interpreting the results, the inference of the authors was carried out, relating them to the quotations, codes and code groups, according to the goal of the investigation and the theoretical support. In this phase, the visualization network and tables with the results were developed as well.

In order to provide a better understanding to the reader, linking theory and researchers' perception, excerpts of answers were highlighted in the discussion section.

\section{RESULTS}

The data furnished by the participants regarding the definition of health were organized in three categories, seven subcategories and 20 codes. The following visualization network illustrates this relation: 


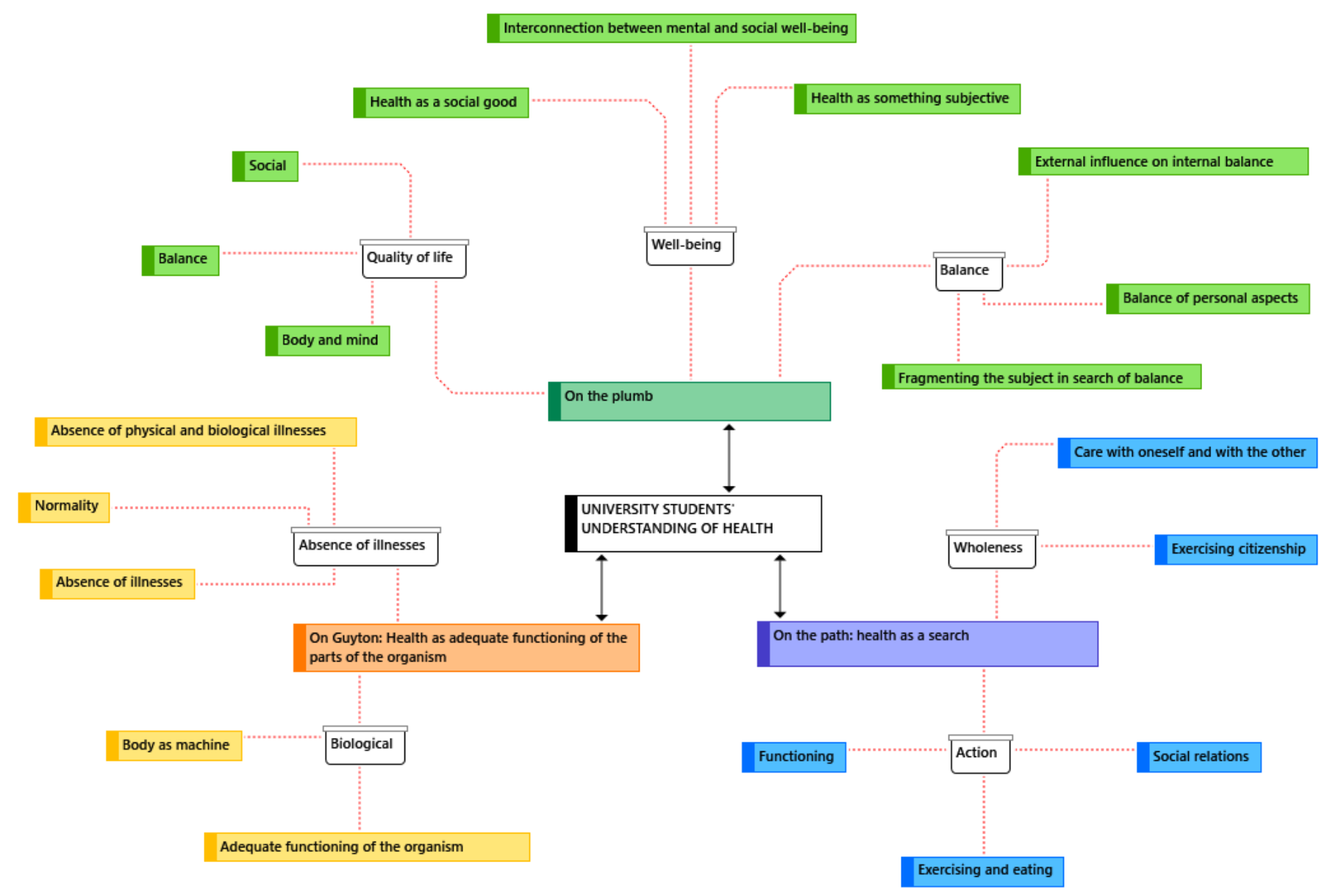

Figure 1. Visualization network of the results

The quantitative of answers is described in Table 2:

In the great majority, health encompasses wellbeing, along with the notion of unbalance. It is noted that health as well-being is the most cited among the students of the first and tenth phase; in the first phases, the definitions were more closed, linked to absence of diseases and to the biological; on the other hand, in the last phases, the views in circulation are more ample, especially linked to definitions of wholesomeness.

Table 2. Number of quotations linked to subcategories and categories regarding the understanding of health by college students from programs in the field of health

\begin{tabular}{lccc}
\hline \multirow{2}{*}{ Categories } & Subcategories & \multicolumn{2}{c}{ Quotations } \\
& Well-being & 122 & 52.5 \\
On the plumb: health as a search for balance, well-being, and quality & Balance & 34 & 14.5 \\
of life & Quality of life & 7 & 3 \\
& Biological & 20 & 8.5 \\
On Guyton: health as the adequate functioning of the parts of the & Absence of illnesses & 21 & 9 \\
organism & Action & 14 & 6 \\
\hline \multirow{2}{*}{ On the path: health as a search } & Wholeness & 15 & 6.5 \\
\hline Total & & 233 & 100 \\
\hline
\end{tabular}

Source: data from the research, 2019. 


\section{DISCUSSION}

\section{On the plumb: health as a seeking for balance, well-being and quality of life}

The plumb is a work tool used by civil construction workers to raise the building in right angle, without unevenness. Thus, in this sense this category gathers definitions converging to balance. Within this category, there are three subcategories that are interconnected between their contents, namely: well-being, balance, and quality of life, which have come up in some quotations as part of the participants' answer, i.e., co-occurrence.

The idea of balance is present in many discussions regarding the concept of health. For Hippocrates o Kos (460-377 BC.), considered as the father of medicine, health consisted in the balance of the different humors of the body: yellow bile, black bile, phlegm, and blood $^{1}$. For some of the references of the biomedical model, health would be the absence of disease, as the expression of the performance of the natural function of each part of the body ${ }^{2}$, whereas the disease, the unbalance of these functions.

The concept proposed by WHO refers to the complete state of physical, mental and social wellbeing, also referring to stability. Nevertheless, by relating well-being to normality, balance and health, it opens to many reflections on what is defined as wellbeing (this could be a subjective category, a subject's self-perception; or else, a construct related to what the social values define as well-being, and so, subject to be standardized).

In the "well-being" subcategory, there are the definitions approaching health as the person's well-being, either in physical, psychological, social and/or spiritual context, and it is subdivided into three codes: health as something subjective, health as a social good, and integration between mind and body.

As an example of the "health as something subjective" code, there is: "Health is the complete physical, mental and psychological well-being; it is personal, that is, it depends on each person" (PO 79). Czeresnia and Freitas ${ }^{12}$ reflect that many times, in health practice, the concepts of sickness (mental construction) and the process of becoming sick (related to the life experience) are confused; hence, it is necessary to understand this difference so that, as health professionals, the simple answers will not be sought; instead, practices will be developed that encompass the totality when promoting health.
In the "health as social good" code, the following comes up: "It is the well-being of all people" (PF 31). To think of health as a social good is something that refers to discussions connected to health promotion movements, as well as schools of thought that debate social health determination on the 1970s and 1980s, and is expressed in the principles of the sanitary reform movement in Brazil. When thinking of health as social good, it is not possible to disconnect the idea of health as a right, for, in this understanding, it is aimed to achieve a perspective in which health is adequate for all, and all have access to it, considering the social impact of this ${ }^{13}$.

The "interconnection between mental and bodily well-being" appears as the third code: "Health is the overall well-being, for in a perception of integrated mind and body, one will affect the other. Therefore, for the body to be well, the mind needs to be well, and viceversa" (PP 58). Still, it is possible to perceive in this discourse the correlation with balance as fundamental to health.

Thus, the subcategory "balance" is formed by 34 answer excerpts characterized by definitions that approach health as the balance of the various factors that influence the person's life, including the physical, mental, social, among others, being created from three codes: balance of personal aspects, external influence on internal balance, and fragmentation in the search for balance.

As an example of the "balance of personal aspects", there is the following excerpt: "Health is something like the balance between all the factors of life: physical, mental, psychological and spiritual" (PM 8). There are also the answers that amplify the issue of balance beyond the subject, encompassing social and environmental aspects in the "external influence on internal balance" code, such as: "Health is the balance of all spheres of life: balance of healthy body, healthy mind, and harmonious balance with the society surrounding the person" (PM 39).

Based on the contributions from the 1974 Lalonde Report, the concept of health was expanded and the relation between the sets of knowledge and practice was highlighted, considering the biological, the lifestyle, the environment, and the models of health services offered ${ }^{14}$, thus including the external, social issue to the perception of health, present, by the way, on the answers given by the participants of this study.

The next code brings in its discourse the "fragmentation of the subject in the search for balance", which 
refers to the old medical paradigm; thus, health "would be that which is provided to people by means of care, with the purpose of achieving a state of balance of the body, trying to keep all parts well, so that the whole will be healthy" (PM 166).

Hence, it is possible to notice that this idea derives from the model proposed by Abraham Flexner, in 1910, as it was from the contributions made by this author that it was established the model that has reminiscences until today in the field of health, in which there is the fragmentation of the subject for the cure, the return to the healthy, to be possible ${ }^{15}$.

At last, the "quality of life" subcategory encompassed seven answers that define health as the capacity the subject has to possess quality of life, originating from three codes: body and mind, balance, and social.

The following excerpt defines the "body and mind" code: "(...) it is the physical and mental quality of life" (PP 57). The definition of quality of life for $\mathrm{WHO}^{16}$ encompasses the perception by the individual of their conditions of life, beliefs, goals, expectations and concerns. Thus, when speaking of quality of life, it speaks of the subjectivity of each subject to realize what is best for them.

In the "balance" code, there was a correlation with other codes, as, for instance: "Health is not the mere absence of illness, but quality of life and balanced life" (PN 552). Therefore, balance goes beyond balance of the organism; it involves the subject's spheres of life and the roles they perform socially, and so furnishing quality of life based on what the subject considers important for themselves.

And in the "social" code, it is reported: "Health for me is to have good quality of life, with social, physical and emotional well-being" (PN 51). Quality of life seems to be linked to promotion of health and social conditions, and it is very important to overcome the biomedical model, especially as it aims to provide health to the people, and not only to eliminate symptoms and illnesses by means of multidisciplinarity in the interventions, being a target of public policies aimed at seeing the subject in their wholesomeness ${ }^{17}$.

The idea of health as balance, as plumb, is persistent in these answers. It is taken as reference the relation of the subject, their body, their mind, their social environment, or the fragmentation of these aspects. Sometimes, it refers to the idea of understanding normality based on control, as if the polarizations or deviations to one of the sides were considered lack of health.

\section{On Guyton: health as adequate functioning of the parts of the organism}

Arthur Clifton Guyton was an American physiologist doctor and, currently, is one of the main literatures dealing with human physiology. Certainly, at some point the students in health graduation programs had to read it. His writings converge to the good bodily functioning, especially emphasizing the normal human physiologic mechanisms. And it is on this Guytonian perception that the present category deals with.

Therefore, here are the subcategories approaching mainly the issue of the body as absence of illnesses and linked to the biological. The understanding of health as absence of illnesses is tributary of the modern clinic. It was initially expressed through a perspective that attributes to the body the sense of a machine, whose good functioning would express its normality, came to be understood as a concept opposed to that of illness, the performance of the natural function of each part of the body, based on a perception of the normal as statistically and functionally defined ${ }^{2}$.

For a long time, the Cartesian model restricted the understanding of the health and illness process to the biological, ignoring its relation to the set of variables that are connected to the process of being ill and being healthy, as the psychological, economic and social variables ${ }^{18}$.

This discourse has been re-signified with the advent of the understanding of neurophysiologic and genetic alterations in the last years; it has run through the discussion on the possibilities of life, or models of life to be followed for the regulation of these standards ${ }^{19}$. Health, then, "no longer has to do only with the absence of illnesses, but also (the possibility of) consuming certain products, medications, that is to say, consuming a certain model of life"19:628, which makes well-being, longevity and life itself possible.

In this category, the "absence of illnesses" subcategory counts with 21 occurrences, which are divided into three codes: absence of illnesses that hinder the quality of life, absence of physical illnesses, and normality. As an example of "absence of illnesses": "Being healthy is presenting physical and psychic well-being; the absence of pathologies that impair the person's functioning and quality of life, in their biological, social and affective aspects" (PP 73). 
There are also definitions that approach health specifically as "absence of physical and biological illnesses": Individual without any pathology (illness), with the absence of signs and symptoms related to NCCD (non-communicable chronic diseases), having control of their physical and mental actions" (PN 139).

It is noticed that the absence of illnesses may be brought about by medications, and it could be related to market interests. The market announces the "magic pill" that alleviates symptoms and cures diseases, but for there to be profit, it is necessary that this idea of "being healthy is when the body is well" be accepted. Therefore, for a long time, it was created and sustained the perception that to be healthy is not to be bodily sick; such logic still is in circulation in society, including among health professionals (and future professionals), who contribute for the pharmacological market to keep on profiting ${ }^{18}$.

Therefore, it is widespread the idea that the people who have access to medications have access to health, becoming healthy and, consequently, becoming capable of controlling their own actions, thoughts and desires. This type of view stimulates people to seek in medication and self-medication a way to be masters of themselves, and so show that they are healthy.

"Normality" appears as the last code of this category, encompassing definitions that approach health as being "normal": "Health is when the organism is in its normal state, without pathologies" (PN 94). Based on this answer, itis made necessary to approach the debate on normalization, which implies a bodily, organic and biological normative parameter, but also psychological and social, trying to mark the identities to the norm. Hence, it is sought to define the person as healthy or sick based on the conformity to, or deviation from what is considered as standard ${ }^{18}$.

This type of view on health does not allow for therapeutic interventions based on the subject's needs, but based on what someone else considers necessary, from a structured, socially imposed norm, without there being questioned what or who defines what is the standard.

The "biological" subcategory encompasses discourses that approach health as derived from the adequate functioning of the organism, i.e., that approach the body issue as the only or the most important health (or not) factor of the individual, being mentioned by 20 participants in the research, and divided in two codes: adequate functioning of the organism, and body as machine.
The "body as machine" code is related to the other codes in this category, represented by the following excerpt: "(...) it is the capacity the body has to maintain inner stability (with the functioning of the organs and systems) in face of countless physical, mental and environmental illnesses found in the environment where one lives" (PM 12). So, the body as a machine that adapts to the interferences appears in the discourse.

The old biological classification, which consisted in the standardization of the organism's biological functioning, this being the basis for comparison of the norm and the deviation of what it is to be healthy ${ }^{18}$. This perception has been overcome and enlarged by the humanities, adding the psychological and the social aspects as fundamental to define what is "normal", though still reducing the subject's actions as healthy or not based on a norm.

It is thus noticed the way by which the power structures are presented through the standardization discourse which is hidden behind the scientific technical discourse; i.e., what is and what is not socially accepted is presented as what is and what is not normal, from the social spaces to the individuals, their bodies, conducts, activities and established relations. It is, then, the biopower being exercised, in which power is exercised by each individual incorporating the norm ${ }^{20}$.

As an example of the "adequate functioning of the organism" code, there is the excerpt: "I understand health as a state in which the organism functions according to its necessities, that is, in which the body functions in the most correct form, furnishing well-being to the person" (PN 45). And: "(...) it is when someone is well with their own body, without having anything that physiologically bothers them" (PM 47).

The notion of adequate functioning indicates that the perception of health is very much associated with the understanding that solution to problems is had, for instance, as in an automobile, to which a regulation, a tightening of a certain screw is enough to adjust the noise. This, in health care practice, may be manifested in the fragmentation of the person, dividing them in parts when offering professional care, but not observing their wholeness.

These answer excerpts also refer to the "(...) scientific discourse, the specialty and the institutional organization of the health practices, which were circumscribed based on objective concepts, not of health, but of disease" ${ }^{\prime \prime}$ (p. 45). This scientific discourse is very much connected to health being viewed as the absence of anatomophysiologic illnesses, in which health is 
provided to the subject through isolated treatment, fragmenting the person; i.e., it is directly related to the "absence of illnesses" subcategory ${ }^{21}$.

\section{On the path: health as a search}

The last category is named "on the path", for its concept of health is the search for it. It counts with two subcategories: wholeness, and action; both involve some movement on the part of the subject to become healthy.

In the "wholeness" subcategory, 15 answers were identified which has a correlation with another category and subcategories (well-being, balance, and quality of life). However, they had broader definitions, i.e., they presented new health-influencing factors that were not present in the answers. In this subcategory, there were two codes: care with oneself and with the other, and exercising citizenship. The following answer demonstrates quite well the "care with oneself and with the other" code:

Health for me is caring for one's neighbor; health is making use of wholeness and education, aiming at a better learning and mental balance performance; for health is not merely physical, it is also mental, psychological, which is the most important in my point-of-vie (PE 1).

Czeresnia and Freitas ${ }^{12}$ analyze that most of the conferences and documents related to promoting health encompasses the understanding of the problems as important for their intervention, valuing also the popular knowledge and the social participation.

Hence, it becomes recognized as important, but it also accepts the popular participation in the way health is produced. Furthermore, it is possible to add that the very exercise of citizenship is health already, as the subject presents themselves as one who possesses knowledge, and becomes active in their own health process.

The "exercise of citizenship" code influences positively the subjects' health; enjoying one's rights is also seen as important for the wholesome health:

In order for the person to have good physical, mental and spiritual health, it is indispensable that their basic needs be supplied, as, for instance, the appropriate living and working environment, safety, financial stability (employment), access to health services, food, times of leisure, and basic sanitation (PEF 548).
The Law 8.080 itself ensures that access to health is everyone's right, and aims to provide that everybody has their needs equally met in Brazil by the Sistema Único de Saúde - SUS (Portuguese for the Brazilian's publicly funded health care system $)^{22}$. Thus, accessing and using one of the facilities of the system is one way to exercise citizenship and ensure one's rights.

The "action" subcategory has 14 answers, and the answers were inserted which had in its discourse the statement that health comes from actions performed by the individual, them being the only one responsible for their own health or for the lack thereof. As an example, there is the "exercise and food" code: "Health is for one to be $100 \%$ well with one's body, with one's mind. To be active with physical exercises, to eat well, to take care of oneself, so that, besides being happy, the body will also be well" (PF 272).

Studies point out that healthy eating promotes, in the long term, the well-being and good functioning of the organism, and, depending on the basis of the diet, will even impact the aging process, ensuring (or not) healthy life then. Nonetheless, it is not restricted to the impact on the organism; it is also related to the psychological well-being ${ }^{23}$. The regular practice of physical exercises has an impact on the subjects' quality of life, but not isolatedly ${ }^{24}$. It is linked to the influence on the quality of life and well-being, though it does not encompass the totality of the meaning of health.

In the "social relations" code, the importance of having social relations in order to be a healthy person is added on the answers, as in: "In order to have a healthy life, it is necessary first to be well with oneself, practice sports, have a healthy diet, make new friends, be open to new knowledge; health is the union of all these factors" (PE 161). And, at last, the "functionality" code appears with the following answer: "Appropriate health conditions (physical and emotional integrity) to accomplish the daily work, fulfill tasks, achieve goals, and plan the future" (PN 278).

In this context, the International Classification of Functioning, Disability and Health (ICF) was developed, with the purpose of organizing information on health and its different conditions. The ICF deals with the degree of functioning of the interaction capacity of the person with themselves, at work, with the family, and with the community; i.e., it takes into consideration the sociocultural condition and the quality of life of the subjects ${ }^{25}$. Thus, an attempt to depart from the illnessfocused model and start to identify potentialities and 
the multiple facets of health is noticed, including the capacity to interact socially.

The approach to health as a search, in the context of public health, has important contributions from historical French epistemology, particularly that from Georges Canguilhem (1904-1995) ${ }^{26}$, who defines health as "the plasticity of life and its infinite possibilities of being lived (...); it develops an original perspective for the understanding of care practices"19:633. His writings have accompanied the academic project of public health in Brazil, influencing the work of Arouca (O dilema preventivista - 1975) and Donangello (Medicina e estrutura social - 1976), which also debate the biomedical paradigm ${ }^{26}$.

Hence, differing from the biomedical characterization of illness, Canguilhem thinks the process health-illness as the potential to create new life forms; therefore, being healthy is related to the capacity of overcoming and creating.

Further on re-signifying the practice of caring in a humanizing perspective, health is being discussed as the conditions for searching, and the handling of the process of becoming ill, with the purpose of accomplishing projects of felicity ${ }^{27}$. In this sense, the health practices are problematized, whose approaches focus on illness, fragmenting the subject, not seeing them in their wholeness.

Concerning health as a path to go along, it is not a point to be reached, a place where one stays after having arrived, but something fluid, which must be continuously thought and thought over, and implemented. Thus, attention given in caring for oneself and for the other makes part of this path.

Regarding the limitations of this study, it is suggested that this phenomenon be perceived as important already in formal training in the university, as health, being the objective or end activity of these future professionals, is related to the perspectives concerning the subject of their practice. Hence, it is also expressed in care practices, and perception of their objectives and of the subjects of this relation.

It would be interesting to analyze how these concepts vary throughout the health programs, and the newly-graduated professionals, in order to verify the influence of the knowledge produced and widespread in the academia on the care practices. From the faculty's perspective, understanding how this process takes place is important to discuss the structuring of the program's courses, as well as the abilities and competences to be developed by the students, so as to provide a comprehension of care based on a perspective of autonomy and wholesomeness of the subjects.

\section{CONCLUSION}

The understanding of the concept of health for the college health students is not unison, and is expressed in a polysemic manner, sometimes converging into the notion of a plumb, sometimes focused on physiological normality and, at last, health as a path to be constructed.

There was a substantial predominance of perceptions connected to well-being and to the notion of balance. In lower intensities, comprehensions based on the absence of illness, and also on a broader perspective, linked to the capacity of each person to act, were seen.

\section{REFERENCES}

1. Scliar M. História do conceito de saúde. Physis. 2007; 17(1):29-41.

2. Batistella C. Abordagens contemporâneas do conceito de saúde. In: Fonseca AF, Corbo AD (orgs). O território e o processo saúde-doença. Rio de Janeiro: EPSJV, Fiocruz; 2007. p.51-86.

3. Organização Mundial Da Saúde (OMS). Constituição da Organização Mundial da Saúde em 1946. Biblioteca virtual de direitos humanos da Universidade de São Paulo. [internet], 1948. [acesso em 17 jun. 2018]. Disponível em: http://www.direitoshumanos.usp.br/index.php/ OMS-Organiza\%C3\%A7\%C3\%A3o-Mundial-daSa\%C3\%BAde/constituicao-da-organizacaomundial-da-saude-omswho.html.

4. Brito J. Saúde - uma relação com o meio e os modos de vida. Laboreal. 2017;13(1):100-3.

5. Caldas JB, Lopes ACS, Mendonça RD, Figueiredo A, Lonts JGA, Ferreira EF et al. A percepção de alunos quanto ao Programa de Educação pelo Trabalho para a Saúde - PET-Saúde. Rev. bras. educ. med. 2012;36(1, supl. 2):33-41.

6. Oliveira ML, Coelho TC. A percepção de acadêmicos de odontologia sobre o PET-Saúde UFMS/ SESAU, Campo Grande/MS, 2009. Revista da ABENO. 2009;11(1):76-80.

7. Oliveira ERA, Fiorin BH, Santos MVF, Gomes MJ. Acolhimento em saúde e desafios em sua implementação: percepção do acadêmico de 
enfermagem. Revista Brasileira de Pesquisa em Saúde. 2010;12(2):46-51.

8. Mialhe FL, Silva CMC. A educação em saúde e suas representações entre alunos de um curso de odontologia. Ciênc. Saúde Coletiva. 2011;16(supl. 1):1555-61.

9. Chizzotti A. Pesquisa em Ciências Humanas e Sociais. São Paulo: Cortez; 2018.

10. Friese S, Soratto J, Pires D. Carrying out a computer-aided thematic content analysis with ATLAS. ti. MMG Working Paper. 2018;18(2):1-30.

11. Bardin L. Análise de conteúdo. Lisboa: Edições 70; 2011.

12. Czeresnia D, Freitas CM. Promoção da saúde: conceitos, reflexões, tendências. 2. ed. 3 reimp. Rio de Janeiro: Editora Fio Cruz; 2014.

13. Saraiva AMP. Acesso à tecnologia em saúde: uma perspectiva bioética [tese]. Porto (Portugal): Faculdade de Medicina da Universidade do Porto; 2015.

14. Carvalho MP, Andrade FP, Baisch ALM, Soares MCF. Saúde para todos: reflexões que permeiam essa meta. Vittalle. 2011;23(2):27-31.

15. Rocha JA, Rocha JÁ, Mendonça MA. Humanizar o humanizado: Universitário Transformador, aperfeiçoando a ótica acadêmica no contexto familiar. Revista Fluminense de Extensão Universitária. 2017;7(2):4-7.

16. Organização Mundial da Saúde. The WHOQOL Group. The World Health Organization quality of life assessment (WHOQOL): position paper from the World Health Organization. Soc. Sci. Med. 1995;41(10):1403-10.

17. Ascef BO, Haddad JPA, Álvares J, Guerra Júnior AA, Costa EA, Acurcio FA et al. Health-related quality of life of patients of Brazilian primary health care. Rev. Saúde Pública. 2017;51(2):1-13.

18. Caponi S, Verdi M, Brzozowski FS, Hellmann F. Medicalização da vida: ética, saúde pública e indústria terapêutica. Palhoça: Editora Unisul; 2010.

19. Neves TI, Porcaro LA, Curvo DR. Saúde é colocar-se em risco: normatividade vital em Georges Canguilhem. Saude soc. 2017;26(3):626-37.

20. Foucault M. Vigiar e punir: nascimento da prisão. 41. ed. Petrópolis, RJ: Vozes; 2013.

21. Canguilheim G. O normal e o patológico. 6. ed. Rio de Janeiro: Forense Universitária; 2009.

22. Lei $n=8.080$, de 19 de Setembro de 1990. Dispõe sobre as condições para a promoção, proteção e recuperação da saúde, a organização e o funcionamento dos serviços correspondentes e dá outras providências. Diário Oficial da União, 19 Set 1990.

23. Prata PM, Marques PH. Saúde e alimentação no trabalho. In: Anais do VII Vertentes e desafios da segurança; 2017 out 26-28; Leiria, Portugal. Leiria: ASVDS; 2017. p. 119-26.

24. Totoro RJ, Sousa M, Martins R, Chacur E, Sousa F. Avaliação da qualidade de vida dos usuários de um Núcleo de Apoio à Saúde da Família - NASF. Psicologia e Saúde em Debate. 2017;3(1):50-7.

25. Organização Mundial da Saúde. Como usar a CIF: um manual prático para o uso da Classificação Internacional de Funcionalidade, Incapacidade e Saúde (CIF). Versão reliminar para discussão. Genebra: OMS; 2013.

26. Ayres JRCM. Georges Canguilhem e a construção do campo da saúde coletiva brasileira. Intelligere. 2016;2(1):139-55.

27. Ayres JRCM. Uma concepção hermenêutica de saúde. Physis. 2007;17(1):43-62. 